\begin{tabular}{|c|c|c|c|c|c|c|}
\hline \multirow{4}{*}{ Impact Factor: } & ISRA (India) & $=3.117$ & SIS (USA) & $=0.912$ & ICV (Poland) & $=6.630$ \\
\hline & ISI (Dubai, UAE & $=0.829$ & РИНЦ (Russia & $=0.156$ & PIF (India) & $=1.940$ \\
\hline & GIF (Australia) & $=0.564$ & ESJI (KZ) & $=8.716$ & IBI (India) & $=4.260$ \\
\hline & JIF & $=1.500$ & SJIF (Morocco & $=5.667$ & OAJI (USA) & $=0.350$ \\
\hline
\end{tabular}

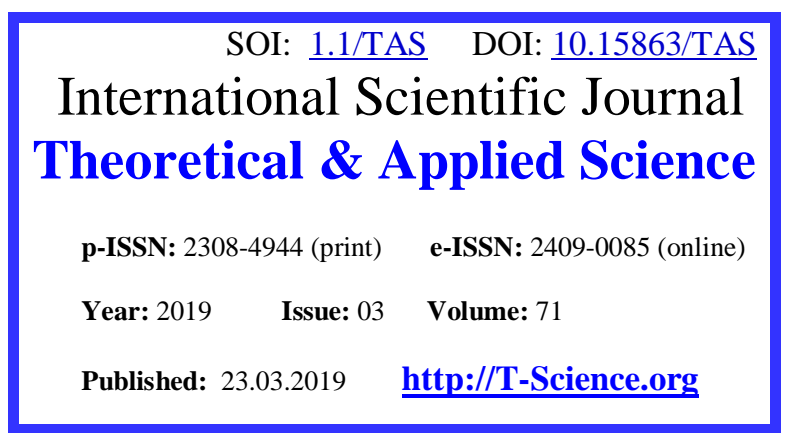

SECTION 11. Biology. Ecology. Veterinary. UDC: 581.582.477.6. (575.111)

\section{International Scientific Journal}

p-ISSN: 2308-4944 (print)

Published: $23.03 .2019 \quad$ http://T-Science.org
QR - Issue

QR - Article

\title{
CURRENT ECOLOGICAL CONDITIONS AND PHYTOCENOTIC \\ DIVERSITY OF THE TUGAI VEGETATION OF THE BASIN OF AKHANGARAN RIVER
}

Abstract: 50 species of plants were registered in the tugai of the basin of Akhangaran river, under grouping those according to life-forms are identified: trees - 5, shrubs - 7, annual and perennial grasses - 38 species. All phytocenotic diversity was united into 4 associations: wild herbs - spinous - yulgun, yulgun - mixed-tugai, saltwortreed-mixed tugai, reed-woody-shrubs.

Key words: ecology, biodiversity, phytocenology, environmental protection, tugai, ecosystems, maps, trees, shrubs, herbaceous plants.

Language: English

Citation: Azimov, I. T. (2019). Current ecological conditions and phytocenotic diversity of the tugai vegetation of the basin of Akhangaran river. ISJ Theoretical \& Applied Science, 03 (71), 352-356.

Soi: http://s-0-i.org/1.1/TAS-03-71-23 Doi: crossef https://dx.doi.org/10.15863/TAS.2019.03.71.23

\section{Introduction}

In the world, special attention is paid to researches, carried out on the characterization of the composition of local vegetation covers, the assessment of the resource viability of vegetation covers, and the monitoring of the processes occurring in the vegetation cover. Especially, to definite the changes of occurring in vegetation in areas with strong anthropogenic pressing processes, it promotes to correct basing of the successive processes with a complex of natural geographic and anthropogenic factors

In this attitude, the basin of Akhangaran river, located between the Chatkal and Kuramin mountain ranges of the Tien Shan - one of the centers of plant biodiversity in Central Asia, by one side, it is characterized by the presence of plant species, typically for all high-altitude zones of Central Asia.[5]

In recent years, environmental protection, ecological balance, rational use of natural resources have become as an international global problem.

This dictates the study of the current state of the vegetation of all altitude belts, in particular, of the tugai of the study area.

\section{Materials and Methods}

Information about the tugai vegetation and the conditions of its habitat in Uzbekistan, in particular the basin of Akhangaran river, can be found in the works of V.P. Drobova, 1956, E.P.Korovin, 1962, A. Bakhiev, 1970, A.U. Usmanov, 1953, A.A. Ashurova, 1965, M.M. Arifkhanova, 1961, N. Temirboev, 1969, Z.A. Mailun, 1973, V.N. Pavlov, 1980, A.A. Khanazarov and E.A. Butkov, 2002 and etc.[2,4,5]

Of great importance in the study of the tugai of the basin of Akhangaran river is the work of A.U. Usmanov (1953) and A.A. Khanazarov, E.A. Butkov (2002) and who are like a bench mark for comparison with our data.

In 2000-2010 years, for the first time in a separate form, it was performed a detailed comprehensive study of the floristic composition, biomorphological, phytocenotic, typological, ecological diversity and the current dynamic state of the plant communities of all high-altitude belts, in particular in the tugai in basin of Akhangaran river by their mapping.

Tugay vegetation, we can call, like many researchers (Usmanov, 1953, Temirbayev, 1969, Maylun, 1973), as the whole plant complex of river valleys. 


\begin{tabular}{|c|c|c|c|c|c|c|}
\hline \multirow{4}{*}{ Impact Factor: } & ISRA (India) & $=\mathbf{3 . 1 1 7}$ & SIS (USA) & $=0.912$ & ICV (Poland) & $=6.630$ \\
\hline & ISI (Dubai, UAE & $=0.829$ & РИНЦ (Russia & $=0.156$ & PIF (India) & $=1.940$ \\
\hline & GIF (Australia) & $=0.564$ & ESJI (KZ) & $=8.716$ & IBI (India) & $=4.260$ \\
\hline & JIF & $=1.500$ & SJIF (Morocco & $=5.667$ & OAJI (USA) & $=0.350$ \\
\hline
\end{tabular}

In the basin of Akhangaran river, tugai occupies a limited place, by stretching along a narrow strip along the river, on the elements of the modern floodplain, which is flooded with spring and summer floods.

The basin of Akhangaran river is located between the south-western spurs of Chatkal and northwestern slopes of the Kuramin ranges.

The total area of the basin, according to our data, is $6226 \mathrm{~km}^{2}$, and on the literature data is $5260 \mathrm{~km}^{2}$. The relief of the basin is characterized by a clearly pronounced vertical zonality.

The Akhangaran river begins above the Kengas passage $(4062 \mathrm{~m})$, before the confluence of the SyrDarya river $(350 \mathrm{~m})-233 \mathrm{~km}$. Along numerous lateral tributaries: Karakiyasai, Shavgazsai, Larek, Lashkerek, Kamchik, Karabausay and etc., where these lateral tributaries there are also a narrow strip of rare tree - shrub tugai.

These thickets with narrow strip are distributed mainly in hard-to-reach steep stony sides of river coasts.

Due to the large spectrum of absolute heights and correspondingly a wide range of ecological conditions, a large phytocenotic and floristic diversity and biota of the ecosystems of this basin are concentrated here. Therefore, botanically attitude, the basin of Akhangaran river as the entire territory of Western Tien - Shan, in particular of tugai, is very interesting, distinctive and strongly transformed (broken).[1,3,4]

The current condition, structures, and areas of vegetation, especially in the tugai communities of the basin, have been significantly changed in recent years under the influence of various types of anthropogenic factors. The entire territory of the basin, especially along the river of floodplain, is covered with a dense network of vehicle roads, with numerous mines, careers, rest houses, water reservoirs and the basin has significant demographic resources, that the basin is the most dynamic area in Western Tien-Shan, where all types of desertification is occurred. In order to preserve the modern phytocenotic diversity of all species of vegetation, in particular in tugai communities, it is necessary to conduct a cartographic inventory based on space data. Considering the above ralation, in the 2000-2010 years, geobotanical, cartographic surveys of vegetation were conducted in all altitudinal zones, in particular in the tugai of the survey area. As a result, it was installed, that the tugai vegetation of the basin is considered to be the most degraded and strongly changed in the structure and in terms of areas, which is not only reduced in places but also gradually is being destroyed that replaced by cultivated lands.

According to the data of A.I. Usmanov (1953), the total number of plant species which are involved in the formation of tugai thickets, defined in 146 species, belonging to 37 families, of which 34 species fall in the proportion of trees and shrubs. The remaining of 112 species are herbaceous plants.[2]

The author describes the following tugai thickets in the basin:

- poplar - ash- tree - poplar - willow - curly tamariks - hornworm - reed.

The above counted floristic and phytocenotic data are the primary materials for comparing the current state of the tugai vegetation of the basin.

As a result of geobotanical, cartographic research, 50 species were recorded in the tugai. Of these: 5 species of trees, 7 species of shrubs, 38 species are grassy plants (table 1).[6,7.8,10]

As can be seen from the table, the floristic composition in comparison with the reference data was reduced to $68 \%$. As a result of our work, it was revealed that among the above listed tugai communities, tamarix and willow remained, and the rests are found in mixed form (table 1), that floristic and phytocenotic diversity and area also decreased to $60-70 \%$.

This is confirmed by A.A. Khanazarov and E.A. Butkov (2002), that in Western Tien-Shan within the Republic of Uzbekistan, in particular, the basin of Akhangaran river, over the past 40 years, the area of forest, in particular tugai lands has decreased from 215 thousand hectares to 112 thousand hectares that more than $41 \%$ area are decreased.[9]

As a result of geobotanical and surveying work in all high-altitude zones, in particular in tugai vegetation as a special phytocenotic complex were analyzed, which occupies a certain place in the national economy. 


\begin{tabular}{|c|c|c|c|c|c|c|}
\hline \multirow{4}{*}{ Impact Factor: } & ISRA (India) & $=3.117$ & SIS (USA) & $=0.912$ & ICV (Poland) & $=6.630$ \\
\hline & ISI (Dubai, UAE & $=0.829$ & РИНЦ (Russia) & $=0.156$ & PIF (India) & $=1.940$ \\
\hline & GIF (Australia) & $=0.564$ & ESJI (KZ) & $=8.716$ & IBI (India) & $=4.260$ \\
\hline & JIF & $=1.500$ & SJIF (Morocco) & $=5.667$ & OAJI (USA) & $=0.350$ \\
\hline
\end{tabular}

Table 1. List of plants in tugai vegetation of the basin of Akhangaran river

\begin{tabular}{|c|c|c|c|c|c|}
\hline Association & 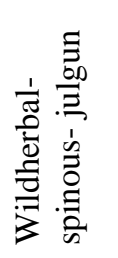 & 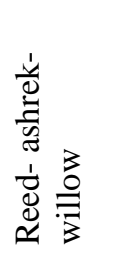 & 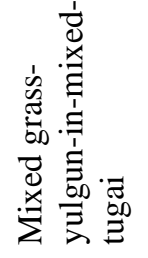 & 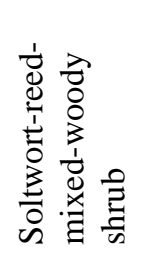 & 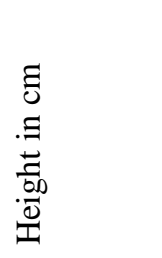 \\
\hline № area & 31 & 17 & 15 & 10 & \\
\hline Projective cover $\%$ & 65 & 70 & 60 & 65 & \\
\hline \multicolumn{6}{|l|}{ Trees } \\
\hline Salix olgae & - & $\mathrm{Sp}_{2}$ & $\mathrm{Sp}_{1}$ & - & $300-400$ \\
\hline S. songarica & - & $\mathrm{Sp}_{3}$ & - & $\mathrm{Sp}_{1}$ & $300-400$ \\
\hline S. wilhelmsiana & - & $\mathrm{Sp}_{3}$ & $\mathrm{Sp}_{1}$ & $\mathrm{Sp}_{2}$ & $200-400$ \\
\hline Elaegnus angustifolia & $\mathrm{Sp}_{1}$ & - & - & $\mathrm{Sp}_{1}$ & $400-500$ \\
\hline Populuspruinosa & - & $\mathrm{Sp}_{2}$ & - & $\mathrm{Sp}_{2}$ & $350-400$ \\
\hline \multicolumn{6}{|l|}{ Кустарники } \\
\hline Tamarixleptostqchys & $\mathrm{Sp}_{3}$ & - & $\mathrm{Sp}_{3}$ & $\mathrm{Sp}_{2}$ & 200 \\
\hline T. litvinovii & $\mathrm{Sp}_{3}$ & - & $\mathrm{Sp}_{2}$ & - & $150-200$ \\
\hline T.hohenackeri & $\mathrm{Sp}_{3}$ & - & - & - & $150-200$ \\
\hline T.pentandra & - & - & $\mathrm{Sp}_{1}$ & $\mathrm{Sp}_{1}$ & 200 \\
\hline T. hispida & - & $\mathrm{Sp}_{1}$ & $\mathrm{Sp}_{1}$ & - & 150 \\
\hline Rosa canina & $\mathrm{Sp}_{2}$ & - & $\mathrm{Sp}_{2}$ & $\mathrm{Sp}_{2}$ & 150 \\
\hline R. beggeriana & - & - & - & $\mathrm{Sp}_{2}$ & 150 \\
\hline \multicolumn{6}{|l|}{ Травы многолетные } \\
\hline Acroptilonrepens & $\mathrm{Sp}_{1}$ & - & $\mathrm{Sp}_{2}$ & $\mathrm{Sp}_{2}$ & $60-80$ \\
\hline Alhagicanescens & $\mathrm{Sp}_{3}$ & & $\mathrm{Sp}_{2}$ & $\mathrm{Sp}_{1}$ & 80 \\
\hline A. pseudalhagi & $\mathrm{Sp}_{3}$ & & $\mathrm{Sp}_{2}$ & $\mathrm{Sp}_{2}$ & $60-80$ \\
\hline Aeluropuslitoralis & $\mathrm{Sp}_{1}$ & - & $\mathrm{Sp}_{1}$ & $\mathrm{Sp}_{1}$ & $200-300$ \\
\hline Agropyronrepens & - & $\mathrm{Sp}_{1}$ & $\mathrm{Sp}_{2}$ & - & $75-85$ \\
\hline Artemisia absinthium & $\mathrm{Sp}_{2}$ & $\mathrm{Sp}_{2}$ & $\mathrm{Sp}_{2}$ & - & $25-40$ \\
\hline Apocynumscabrum & - & - & $\mathrm{Sp}_{1}$ & - & 150 \\
\hline Equisetum ramosissimum & $\mathrm{Sp}_{1}$ & - & $\mathrm{Sp}_{1}$ & $\mathrm{Sp}_{1}$ & $20-25$ \\
\hline Calystegiasepium & $\mathrm{Sp}_{2}$ & $\mathrm{Sp}_{2}$ & $\mathrm{Sp}_{2}$ & - & $15-20$ \\
\hline Calamagrostisdubia & $\mathrm{Sp}_{2}$ & $\mathrm{Sp}_{1}$ & $\mathrm{Sp}_{2}$ & - & $80-90$ \\
\hline Cirsiumochrolepideum & $\mathrm{Sp}_{1}$ & & $\mathrm{Sp}_{2}$ & $\mathrm{Sp}_{1}$ & 70 \\
\hline Centaureasquarrosa & $\mathrm{Sp}_{2}$ & - & $\mathrm{Sp}_{1}$ & $\mathrm{Sp}_{1}$ & $60-80$ \\
\hline Dodartiaorientalis & - & $\mathrm{Sp}_{1}$ & - & $\mathrm{Sp}_{1}$ & $30-35$ \\
\hline Plantagolanceolata & - & - & $\mathrm{Sp}_{2}$ & - & $15-20$ \\
\hline
\end{tabular}




\begin{tabular}{|c|c|c|c|c|c|c|}
\hline \multirow{4}{*}{ Impact Factor: } & ISRA (India) & $=\mathbf{3 . 1 1 7}$ & SIS (USA) & $=0.912$ & ICV (Poland) & $=6.630$ \\
\hline & ISI (Dubai, UAE & $=0.829$ & РИНЦ (Russia & $=0.156$ & PIF (India) & $=1.940$ \\
\hline & GIF (Australia) & $=0.564$ & ESJI (KZ) & $=8.716$ & IBI (India) & $=4.260$ \\
\hline & JIF & $=1.500$ & SJIF (Morocco & $=5.667$ & OAJI (USA) & $=0.350$ \\
\hline
\end{tabular}

\begin{tabular}{|c|c|c|c|c|c|}
\hline Glycyrrhisadlabra & $\mathrm{Sp}_{1}$ & $\mathrm{Sp}_{1}$ & $\mathrm{Sp}_{1}$ & - & $25-40$ \\
\hline Phragmitesaustralis & $\mathrm{Sp}_{1}$ & $\mathrm{Sp}_{3}$ & $\mathrm{Sp}_{1}$ & $\mathrm{Sp}_{3}$ & $5-75$ \\
\hline Rumexcrispus & - & $\mathrm{Sp}_{1}$ & - & - & 70 \\
\hline R. angreni & $\mathrm{Sp}_{1}$ & - & - & - & $60-75$ \\
\hline Menthaasiatica & $\mathrm{Sp}_{1}$ & $\mathrm{Sp}_{1}$ & - & - & 40 \\
\hline Capparisspinosa & $\mathrm{Sp}_{1}$ & - & $\mathrm{Sp}_{1}$ & - & 120 \\
\hline Circiumochrolepidium & - & $\mathrm{Sp}_{2}$ & & $\mathrm{Sp}_{1}$ & 75 \\
\hline Cynodondactylon & - & $\mathrm{Sp}_{3}$ & $\mathrm{Sp}_{1}$ & - & $20-25$ \\
\hline Cyperusrotundus & - & $\mathrm{Sp}_{2}$ & - & - & $15-20$ \\
\hline Cichoriumintybus & $\mathrm{Sp}_{1}$ & $\mathrm{Sp}_{2}$ & - & $\mathrm{Sp}_{1}$ & $50-75$ \\
\hline \multicolumn{6}{|c|}{ Herbs perennial and annual Projective coverage $\%$} \\
\hline Medicagolupulina & - & $\mathrm{Sp}_{1}$ & $\mathrm{Sp}_{1}$ & - & 20 \\
\hline Anagalisarvensis & - & $\mathrm{Sp}_{1}$ & - & $\mathrm{Sp}_{1}$ & $10-15$ \\
\hline Galiumtricorne & $\mathrm{Sp}_{2}$ & - & $\mathrm{Sp}_{2}$ & - & $20-30$ \\
\hline Polyganumaviculare & $\mathrm{Sp}_{1}$ & $\mathrm{Sp}_{1}$ & $\mathrm{Sp}_{1}$ & - & $15-25$ \\
\hline Phleumpanicylatum & & $\mathrm{Sp}_{1}$ & & $\mathrm{Sp}_{2}$ & $15-20$ \\
\hline Chenopodium album & - & - & $\mathrm{Sp}_{2}$ & - & $35-45$ \\
\hline Ch. Botrys & - & $\mathrm{Sp}_{1}$ & $\mathrm{Sp}_{2}$ & $\mathrm{Sp}_{1}$ & $40-50$ \\
\hline Carthamusturkestanica & $\mathrm{Sp}_{2}$ & $\mathrm{Sp}_{2}$ & - & $\mathrm{Sp}_{1}$ & $35-45$ \\
\hline C. oxyacantha & $\mathrm{Sp}_{1}$ & $\mathrm{Sp}_{2}$ & - & - & $25-40$ \\
\hline Onopordunacanthium & $\mathrm{Sp}_{1}$ & $\mathrm{Sp}_{2}$ & - & - & $75-90$ \\
\hline O. leptolepis (olgae) & - & $\mathrm{Sp}_{2}$ & - & $\mathrm{Sp}_{2}$ & 100 \\
\hline Centaureabelangeriana & $\mathrm{Sp}_{2}$ & $\mathrm{Sp}_{2}$ & - & - & $75-80$ \\
\hline Salsolagemascens & - & $\mathrm{Sp}_{1}$ & - & - & $15-20$ \\
\hline S. carianata & - & - & $\mathrm{Sp}_{1}$ & - & $15-20$ \\
\hline
\end{tabular}

On the "Map of vegetation of the basin of Akhangaran river" (M1: 200000) by small narrow stripes in the riverbed part of the floodplain and on the dam slopes there are the following associations of the tugai type:

- wildherbal- spinous- julgun,

- yulgun-mixedtugai,

- saltwort-reed-mixedtugai,

- reed-woodye-shrubs.

These river thickets are of particular importance in the economy of the studied area. Tree tugai make up an important forestry facility. Poplar, zhida, willow wood is used for fuel and is used as a building material for the construction of bridges and local type housing.[10]

Herbal tugai is a potential source of natural fodder for the development of public animal husbandry. These are mainly grasslands, which provide roughage for the wintering period of all types of livestock. In addition, another major value of tugai forests is water regulation and coast protection. But the reduction of their space continues in all of the survey area. Therefore, all available valuable forest areas, in particular in tugai, it is necessary to take control and carry out inventory work here by drawing up thematic maps using space materials and modern cartographic methods.

The "Vegetation" map is a graphic model of vegetation, which reflects not only the patterns of distribution of mapped units, but also anthropogenic modifications, where the degree of their disturbance is shown on the map by indices of A, B, and C.

The cartographic approach to the study of tugai communities makes it possible in the long term to use it rationally, to predict negative processes and to determine the optimal methods of protection from desertification of the type of being studied of vegetation. 


\begin{tabular}{|c|c|c|c|c|c|c|}
\hline \multirow{4}{*}{ Impact Factor: } & ISRA (India) & $=\mathbf{3 . 1 1 7}$ & SIS (USA) & $=0.912$ & ICV (Poland) & $=6.630$ \\
\hline & ISI (Dubai, UAE & $=0.829$ & РИНЦ (Russia & $=0.156$ & PIF (India) & $=1.940$ \\
\hline & GIF (Australia) & $=0.564$ & ESJI (KZ) & $=8.716$ & IBI (India) & $=4.260$ \\
\hline & JIF & $=1.500$ & SJIF (Morocco & $=5.667$ & OAJI (USA) & $=0.350$ \\
\hline
\end{tabular}

In recent years, the active development of new territories, the intensification of economic activity, in particular the use of plant, forest, and tugai resources, it was put the urgent task of developing the theoretical basis for biodiversity conservation of existing ecosystems in front of botanical, cartographic, forest science and eco-movement in general. Protecting the environment from irreversible depletion (desertification) by identifying optimal methods for combating desertification, as well as clarifying ways to restore rare, endangered species, plant communities and protect the gene pools of the studied area.

\section{Conclusions:}

1. As a result of conducted research, 50 species were recorded in tugai, their biomorphological spectra were identified - 5 species of trees, 7 species of shrubs, and 38 grassy species.

2. 4 associations were identified in the tugai: wild herbal-spinous-yulgun, yulgun-mixed tugai, saltwort- reed - mixed tugai, reed - woody - mixed tugai.

3. The obtained results can be used by planning agencies in the harvesting of forest and pasture resources, reconstruction, and the determination of methods of combating their reduction and measures for the protection of the tugai-type gene pool of the survey area.

\section{References:}

1. Drobov, V. P. (1956). Features of the zonal distribution of the vegetation of the Kuramin Range in the Western Tien Shan. Academician V.N. Sukachev on his 75th birthday. (p.150). ML.

2. Usmanov, A. U. (1953). Tugai vegetation of the Angren River valley. (pp.1-20). Tashkent: Publishers of the Academy of Sciences of the Republic of Uzbekistan.

3. Ashurova, A. A. (1965). The vegetation of the valley and the Amu-Darya delta and its economic use. Abstract Doctoral dissertation. (pp.3-25). Tashkent.

4. Arifkhan, M. M. (1961). Tugai Fergana Valley. Proceedings. Tashkent State University. New, series issue 187. Biol. Sciences, kN.38. Botany, 37-41.

5. Korovin, E. P. (1962). vegetation of Central Asia and South Kazakhstan. (pp.202-210). Tashkent.

6. Temirboev, N. (1969). Tugaynaya vegetation of the valley of the river Chirchik. In the book.
Essays on the geography of vegetation of the RUz. (pp.179-210). Tashkent: Publishing house "Fan" Republic of Uzbekistan.

7. Mailun, Z. A. (1973). Tugai vegetation Potamophyta. In the book. Vegetation cover of Uzbekistan. Volume 2. (pp.303-376). Tashkent: Publishing House "fan" RUz.

8. Pavlov, V. N. (1980). Patterns of vegetation cover of the Western Tien Shan. Abstract dock. Diss. (pp.3-30). Moscow.

9. Khanazarov, A. A., \& Butkov, E. A. (2002). Problems of conservation of genetic diversity of tree and shrub species in the mountain forest ecosystems of the Western Tien Shan. In the book. Biodiversity of the Western Tien Shan, protection and rational use. (pp.236-240). Tashkent: Publishing house "EninorENK".

10. Azimov, I. T. (2005). Mapping of pasture vegetation in the Akhangaran river basin. Ecological Bulletin. Tashkent: Chinor ENK, №5, 28-31. 